\title{
EFFECT OF NESFATIN-1 ON ISCHAEMIA-REPERFUSION INJURY IN ISOLATED HEART OF ALBINO RATS
}

\author{
Mohamed S. Tawfik, Dalia I. Abd Al-Aleem, Reham H. Ibrahim and Rehab A. Abaza \\ Physiology Department, Faculty of Medicine, Zagazig University
}

Corresponding Author:

Reham H. Ibrahim.

Tel: 01144963609

Email:

physiology_lover_4@yahoo.com

\section{ABSTRACT}

Background: Nesfatin-1 is a hypothalamic neuropeptide which is involved in control of food intake and glucose homeostasis. Lower plasma level of Nesfatin-1 in patients with acute myocardial infarction (AMI) was reported.

Objective: This study was designed to explore possible effect of Nesfatin-1 on ischemia-reperfusion injury in isolated heart of adult male albino rats and to explain the possible involved mechanisms, in a trial to clarify Nesfatin-1 expected cardioprotective effect.

Design: This study was carried out on eighteen adult male albino rats which were divided equally $(n=6)$ into 3 groups: Group I (ischemia-reperfusion I/R group); hearts were stabilized then subjected to (I/R) protocol, Group II (Nesfatin-1 preconditioning group); Nesfatin-1 was infused for 20 minutes before hearts were subjected to ischemia and Group III (Nesfatin-1 post-conditioning group); Nesfatin1 was infused for 20 minutes at the beginning of 120 minutes of reperfusion. Cardiac performance indicators as left ventricular pressure (LVP), +max (LV dp/dt), -max $(\mathrm{LVdP} / \mathrm{dt})+$, in addition to heart rate were recorded. Lactate dehydrogenase (LDH), creatine kinase-MB (CK-MB), superoxide dismutase (SOD) and C-reactive protein (CRP) were measured in the collected perfusate and cardiac Malondialdehyde (MDA) was measured. Finally, Nitro blue tetrazolium stain was used to detect the necrotic tissue percentage to the whole left ventricular mass.

Results: In group III (post conditioning group), there was a significant increase of the studied cardiac parameters compared to group I (I/R). Nesfatin-1 significantly increased LVP, +max (dp/dt), - max (dp/dt) and HR in comparison with $\mathrm{I} / \mathrm{R}$ group. This was associated with a significant decrease in LDH and CK-MB levels, a significant increase in SOD level and a significant decrease in MDA and CRP levels. Moreover, Nesfatin-1 caused a significant decrease in percentage of necrotic tissue to the whole left ventricular mass. Regarding group II, no significant changes were detected in all parameters except for significant increase in SOD level and significant decrease in CRP level.

Conclusion: Nesfatin-1 protects against ischemia/reperfusion injury in vitro through its antioxidant and anti-inflammatory properties by limiting the infarction area, only if given as a post conditioning factor after I/R. Those results open the way to include Nesfatin-1 among the strategies for management of cardiac infarction during reperfusion.

Key words: Nesfatin-1, cardiac ischemia-reperfusion, oxidative stress, inflammation.

\section{INTRODUCTION}

$\mathbf{N}^{2}$ esfatin-1 is a hypothalamic neuropeptide composed of 82 amino acids with a molecular weight of $9.8 \mathrm{kDa}$, it is derived from the larger protein nucleobindin2 (NUCB2) ${ }^{[1,2,3]}$.

Nesfatin-1 gene is expressed in the hypothalamic nuclei that involved in feeding behavior, food intake, body weight control and glucose homeostasis ${ }^{[4,5]}$. The mRNA expression of Nesfatin-1 is significantly decreased by fasting and significantly increased in the hypothalamus on refeeding, suggesting that Nesfatin-1 is an anorexigenic hormone ${ }^{[6]}$.
In addition to regulating appetite ${ }^{[5]}$, Nesfatin1 plays key roles in energy homeostasis and metabolism ${ }^{[7,8]}$. In the last few years, Nesfatin-1 was considered an adipocytokine ${ }^{[9]}$ with a close relationship found between this peptide and diabetes, as its plasma levels were reduced in type II diabetic patients ${ }^{[10]}$. In fact, Nesfatin-1 elicits anti-hyperglycemic effects ${ }^{[11]}$ and its levels in serum of obese individuals were decreased significantly as the degree of obesity increased (from obese to morbid obese) ${ }^{[12]}$.

Interestingly, rat heart constitutively expresses both the precursor NUCB2 and the protein Nesfatin-1 $1^{[1,13]}$. This expression is 
comparable to that detected in the brain, which is known to be Nesfatin-1-producing organ ${ }^{[14]}$. Accordingly, the cardiac tissue appears to be a source for Nesfatin-1, which may act in a paracrine/autocrine manner on the heart itself and this expression of Nesfatin-1 and the precursor NUCB2 allows the inclusion of the peptide in the growing list of cardiac hormones ${ }^{[15]}$. Furthermore, lower plasma level of Nesfatin-1 in patients with acute myocardial infarction (AMI) was reported ${ }^{[\mathbf{1 6}]}$.

In patients with AMI, the treatment of choice for reducing acute myocardial ischemic injury and limiting $\mathrm{MI}$ size is and effective myocardial reperfusion using either thombolytic therapy or primary percutaneous coronary intervention (PPCI). However, the process of reperfusion can itself induce cardiomyocyte death, known as myocardial reperfusion injury, for which there is still no effective therapy ${ }^{[17]}$. Moreover, it is possible to say that oxidative and inflammatory response activation are extremely important in ischemia-reperfusion phenomenon ${ }^{[18]}$.

(MI/R)injury It is worth saying that Nesfatin- 1 could serve a neuro and gastroprotective function by supporting the balance in oxidant and antioxidant systems and by affecting inflammatory profile ${ }^{[19,20,21]}$,So the reduced expression of Nesfatin-1 may play a role in the pathogenesis of $M I / R$ injury ${ }^{[19,20]}$. Moreover, administration of exogenous Nesfatin-1 may play a cardioprotective effect in those patients.

The aim of this study is to explore the possible effect of Nesfatin-1 on ischemiareperfusion injury in isolated heart of adult male albino rats and to explain the possible involved mechanisms, in a trial to clarify its expected cardioprotective effect.

\section{Animals}

\section{MATERIAL AND METHODS}

A total number of eighteen adult male albino rats of the local strain weighing $200-250 \mathrm{gm}$ were used. All the animals were bred in the animal house of Faculty of Veterinary Medicine Zagazig University. Animals had free access to water, kept at room temperature and were maintained on a $12 \mathrm{~h}$ light/dark cycle. The rats were accommodated to animal house conditions for two weeks before the experiments going on and all investigations were conducted in accordance with the guiding principles for the care and use of research animals and were approved by the Institutional Research Board. Rats were divided into three equal groups $(n=6)$ :

Group I: Ischemia-reperfusion (I/R) group, in which isolated hearts were stabilized then subjected to (I/R) protocol, where the hearts were subjected to $30 \mathrm{~min}$. of global no flow ischemia followed by $120 \mathrm{~min}$. of reperfusion.

Group II: Nesfatin-1 pre-conditioning group, in which Nesfatin-1(Sigma) (100 pmol /L) ${ }^{[15]}$ was infused for $20 \mathrm{~min}$. before hearts were subjected to the ischemia -reperfusion protocol.

Group III: Nesfatin-1 post-conditioning group, in which Nesfatin-1(100 pmol /L) ${ }^{[15]}$ was infused for $20 \mathrm{~min}$. at the beginning of $120 \mathrm{~min}$. reperfusion in the course of ischemia -reperfusion protocol

\section{Methods}

\section{A- Isolated Heart Preparation}

rats were anesthetized with urethane (ethyl carbamate) $25 \%$ freshly prepared solution in a dose of $1.75-2 \mathrm{gm} / \mathrm{kg}$ injected intraperitoneally ${ }^{[29]}$.-After stabilization of anaesthesia, the animal was placed on aboard in the supine position .The four limbs were extended and fixed to the sides of the board .A midline longitudinal incision started just below the neck and extended to the sternum, the hearts were rapidly excisedand placed in ice-cold Krebs-Henseleit buffer. Then the hearts were suspended to a Langendorff apparatus and retrogradely perfused via aorta at a constant flow rate $(12 \mathrm{ml} /$ minute $)$ with the Krebs-Henseleit buffer in a nonrecirculating way ${ }^{[22,23]}$.

Left ventricular pressure (LVP) was measured with a pressure transducer connected via a catheter to a latex balloon placed in the left ventricle through the left atrium. The balloon was filled with water to achieve a left ventricular end diastolic pressure (LVEDP) of about $5 \mathrm{mmHg} .{ }^{[22,23]}$.

\section{B-Experimental protocol:}

\section{- Ischaemia- reperfusion protocol}

After preparation of the recording system, each heart was allowed to stabilize for $40 \mathrm{~min}$ and perfused by Krebs-Henseleit 
solution in the langendorff apparatus at a constant flow rate of $12 \mathrm{ml} / \mathrm{min}$ (which was adjusted with a constant-flow perfusion pump) and temperature of $37^{\circ} \mathrm{C}$; at this time, baseline parameters were recorded.

After stabilization, hearts were randomly assigned to one of the groups described above and subjected to $30 \mathrm{~min}$ of global, no-flow ischemia (by arresting the perfusion pump), during ischemia the hearts were maintained at $37^{\circ} \mathrm{C}$ by the surrounding medium. This ischemia was followed by 120 minutes of reperfusion ${ }^{[15,24]}$.

\section{-Cardiac function assessment}

Using Power Lab 4/3 with bridge amplifier, Signals were analyzed by Lab Chart Pro software .Heart rate and LVP were measured and the maximum rates of positive and negative changes in LVP $( \pm \mathrm{dP} / \mathrm{dt})$ were calculated throughout the entire time course of reperfusion to get the following cardiac performance indicators: Left ventricular pressure (LVP), the maximal values of the first derivative of LVP, $[+(\mathrm{LVdP} / \mathrm{dt})$ $\max , \mathrm{mmHg} / \mathrm{s}]$, which indicates the maximal rate of left ventricular contraction $[\mathbf{1 5 , 2 5 , 2 6 , 2 7 ]}$,

the maximal rate of left ventricular pressure decline of LVP [-LVdP/dt) max, $\mathrm{mmHg} / \mathrm{s})$ ], which indicates the maximal rate

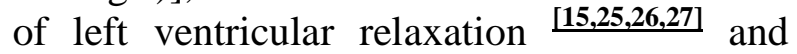
Hear rate (HR) (beat/min.).

Determination of myocardial infarction area using Nitro blue tetrazolium stain (photos 1, 2, 3): to obtain infarct areas, hearts were rapidly removed from the perfusion apparatus at the end of reperfusion, and the left ventricle was dissected into 2 to 3 $\mathrm{mm}$ circumferential slices. After $20 \mathrm{~min}$ of incubation at $37^{\circ} \mathrm{C}$ in $0.1 \%$ solution of Nitro blue tetrazolium in phosphate buffer, unstained necrotic tissue was carefully separated from stained viable tissue. The weights of the necrotic and non-necrotic tissues were then determined, and the necrotic mass was expressed as a percentage of total left ventricular mass, including the septum $[15,23,24,28]$.

\section{C- Biochemical analysis:}

The reperfusion fluid for each rat was collected throughout the total reperfusion period (120 minutes) and stored at $-20 \mathrm{c}$ in in a dark container until assaying of the followings:

- Lactate dehydrogenase (LDH), which was measured Spectrophotometrically using Vitro Scient, Egypt kits according to the method described by Moss et al ${ }^{[29]}$.

- Creatine kinase-MB (CK-MB), which was measured Spectrophotometrically using Pointe Scientific, Inc. USA kits according to the method described by Oliver, 1955 and modified by Rosaki[30]and Szasz et al ${ }^{[31]}$.

-Super oxide dismutase (SOD), which was assayed by a modified Spectrophotometric Assay using Bio diagnostic, Egypt kits according to the method of Kakker et al ${ }^{[32]}$. -C- reactive protein (CRP) was measured by Immuno-enzymometric assay using Monobind, Inc. Lake Forest, Ca 92630, USA kits according to Ridker et al ${ }^{[33]}$.

-The rest of the hearts (after dissection of the left ventricle for staining) were frozen and stored at -20C until analysis of malondialdehyde (MDA) by a spectrophotometer at $534 \mathrm{~nm}$ using Bio diagnostic, Egypt kits ${ }^{[34]}$.

\section{Statistical analysis}

The data obtained in the present study were expressed as mean \pm SD for quantitative variables and statistically analyzed by using SPSS program (version 18 for windows) (SPSS Inc. Chicago, IL, USA). One way analysis of variance (ANOVA) was done followed by LSD test and P value $<0.05$ was considered statistically significant.

\section{RESULTS}

Table 1 shows effect of ischaemia reperfusion, application of Nesfatin-1 pre ischemic (100 pmol/L) and Nesfatin-1 post ischemic (100 pmol/L) on all measured parameters in the three studied groups.

\section{Left ventricular pressure (LVP)}

In group I (I/R) LVP was found to range from 18.4 to $33.6(\mathrm{mmHg})$ with mean $\pm \mathrm{SD}(25.6 \pm$ 5.8) (mmHg).In group II (Nesfatin-1 Preconditioning) LVP was found to range from 22.2 to $38.7(\mathrm{mmHg})$ with mean $\pm \mathrm{SD}(28.2 \pm$ 5.8) (mmHg). The results showed no significant change $(\mathrm{P}>0.05)$ when compared to that of group I. In group III (Nesfatin-1 Post-conditioning) LVP was found to range from 62.6 to $77.4(\mathrm{mmHg})$ with mean $\pm \mathrm{SD}$ $(69.7 \pm 5.3)(\mathrm{mmHg})$ and there was a 
significant increase $(\mathrm{P}<0.001)$ when compared to that of group I and group II.

\section{$+\max (\mathrm{LV} \mathrm{dp} / \mathrm{dt})$}

In group I (I/R) + max ( $\mathrm{LV} \mathrm{dP/dt)} \mathrm{was} \mathrm{found}$ to range from 904 to $1394(\mathrm{mmHg})$ with mean \pm SD $(119.3 \pm 203.7)(\mathrm{mmHg} / \mathrm{s}) . \mathrm{In}$ group II (Nesfatin-1 Pre-conditioning) + max ( $\mathrm{LV} \mathrm{dP/dt)} \mathrm{was} \mathrm{found} \mathrm{to} \mathrm{range} \mathrm{from} 1109$ to $1704(\mathrm{mmHg} / \mathrm{s})$ with mean \pm SD $(1412.0 \pm$ 240.6) $(\mathrm{mmHg} / \mathrm{s})$. The results showed no significant change $(\mathrm{P}>0.05)$ when compared to that of group I. In group III (Nesfatin-1 Post-conditioning) $+\max (\mathrm{LV} \mathrm{dP} / \mathrm{dt})$ was found to range from 2061 to $2673(\mathrm{mmHg} / \mathrm{s})$ with mean $\pm \mathrm{SD}(2361.2 \pm 228.8)(\mathrm{mmHg} / \mathrm{s})$ and there was a significant increase $(\mathrm{P}<0.001)$ when compared to that of group I and group II.

\section{- $\max (L V$ dp/dt)}

In group I (I/R) - max ( $\mathrm{LV} \mathrm{dP/dt)} \mathrm{was} \mathrm{found}$ to range from 611 to $943(\mathrm{mmHg} / \mathrm{s})$ with mean \pm SD $(776.5 \pm 122.8)(\mathrm{mmHg} / \mathrm{s})$.

In group II (Nesfatin-1 Pre-conditioning) $\max (\mathrm{LV} \mathrm{dP} / \mathrm{dt})$ was found to range from 854 to $1194(\mathrm{mmHg} / \mathrm{s})$ with mean $\pm \mathrm{SD}$ $(982.8 \pm 117.9)(\mathrm{mmHg} / \mathrm{s})$. The results showed no significant change $(\mathrm{P}>0.05)$ when compared to that of group .In group III (Nesfatin-1 Post-conditioning) - $\max$ (LV $\mathrm{dP} / \mathrm{dt}$ ) was found to range from 1108 to $1397(\mathrm{mmHg} / \mathrm{s}) \quad$ with mean $\pm \mathrm{SD}$ $(1263.8 \pm 111.1)(\mathrm{mmHg} / \mathrm{s})$ and there was a significant increase $(\mathrm{P}<0.001)$ when compared to that of group I and group II.

\section{Heart rate (HR)}

In group I (I/R) HR was found to range from 59.7 to 75.13 (beat $/ \mathrm{min}$ ) with mean $\pm \mathrm{SD}$ (66.9 \pm 6.1$)$ (beat/min).In group II (Nesfatin-1 Pre-conditioning) HR was found to range from 73.3 to 89.5 (beat $/ \mathrm{min}$ ) with mean \pm SD (79.66 \pm 5.9 ) (beat $/ \mathrm{min})$. The results showed no significant change $(\mathrm{P}>0.05)$ when compared to that of group I. In group III (Nesfatin-1 Post-conditioning) HR was found to range from 90.2 to 105.3 (beat $/ \mathrm{min}$ ) with mean \pm SD $(98.1 \pm 5.6)($ beat $/ \mathrm{min})$ and there was a significant increase $(\mathrm{P}<0.001)$ when compared to that of group I and group II.

\section{Lactate dehydrogenase}

In group I (I/R) (LDH) level was found to range from 168 to 217 (IU/L) with mean \pm SD
(199.8 \pm 21.8$)$ (IU/L).In group II (Nesfatin-1 Pre-conditioning) (LDH) level was found to range from 180 to 205 (IU/L) with mean \pm SD $(195.3 \pm 8.8)$ (IU/L). The results showed no significant change $(\mathrm{P}>0.05)$ when compared to that of group I.In group III (Nesfatin-1 Post-conditioning) (LDH) level was found to range from 40 to 86 (IU/L) with mean \pm SD $(59.5 \pm 18.7)(\mathrm{IU} / \mathrm{L})$ and there was a significant increase $(\mathrm{P}<0.001)$ when compared to that of group I and group II.

\section{Creatine kinase-MB (CK- MB)}

In group I (I/R) (CK- MB) (IU/L) was found to range from 557to 813 (IU/L) with mean \pm SD $(707.2 \pm 110.5)($ IU/L). In group II (Nesfatin-1 Pre-conditioning) (CK- MB) (IU/L) was found to range from 541 to 802 $(\mathrm{IU} / \mathrm{L})$ with mean $\pm \mathrm{SD}(679 \pm 114.3)(\mathrm{IU} / \mathrm{L})$ .The results showed no significant change $(\mathrm{P}>0.05)$ when compared to that of group I. In group III (Nesfatin-1 Post-conditioning) (CKMB) was found to range from 114 to 221 (IU/L) with mean \pm SD $(153.5 \pm 37.2)($ IU/L) and there was a significant increase $(\mathrm{P}<0.001)$ when compared to that of group I and group II.

\section{Superoxide dismutase (SOD)}

In group I (I/R) SOD was found to range from 15.2 to 22.18 (IU/L) with mean \pm SD $(18.7 \pm$ 2.5) (IU/L). In group II (Nesfatin-1 Preconditioning) SOD was found to range from 38.2 to 55.1 (IU/L) with mean \pm SD $(47.6 \pm$ 6.2) (IU/L).The results showed a significant increase $(\mathrm{P}<0.001)$ when compared to that of group I. In group III (Nesfatin-1 Postconditioning) SOD was found to range from 109.6 to 118 (IU/L) with mean \pm SD (113.6 \pm 3.1) (IU/L) and there was a significant increase $(\mathrm{P}<0.001)$ when compared to that of group I and group II.

\section{Malondialdhyde (MDA)}

In group I (I/R) MDA was found to range from 5.58 to 8.17 (nmol/gm tissue protein) with mean \pm SD $(6.94 \pm 1.15)(\mathrm{nmol} / \mathrm{gm}$ tissue protein). In group II (Nesfatin-1 Preconditioning) MDA was found to range from 4.83 to 8.05 (nmol/gm tissue protein) with mean $\pm \mathrm{SD}(6.5 \pm 1.2) \quad(\mathrm{nmol} / \mathrm{gm}$ tissue protein). The results showed no significant change $(\mathrm{P}>0.05)$ when compared to that of group I. In group III (Nesfatin-1 Postconditioning) MDA was found to range from 
1.52 to 3.8 (nmol/gm tissue protein) with mean \pm SD $(3.04 \pm 0.83)(\mathrm{nmol} / \mathrm{gm}$ tissue protein) and there was a significant decrease $(\mathrm{P}<0.001)$ when compared to that of group I and group II.

\section{C-reactive protein (CRP)}

In group I (I/R) CRP was found to range from 423to $475(\mu \mathrm{g} / \mathrm{L})$ with mean $\pm \mathrm{SD}$ $(447.5 \pm 20.8)(\mu \mathrm{g} / \mathrm{L})$. In group II (Nesfatin-1 Pre-conditioning) CRP was found to range from 289 to $360(\mu \mathrm{g} / \mathrm{L})$ with mean $\pm \mathrm{SD}$ $(336.0 \pm 25.9)(\mu \mathrm{g} / \mathrm{L})$. The results showed a significant decrease $(\mathrm{P}<0.001)$ when compared to that of group I. In group III (Nesfatin-1 Post-conditioning) CRP was found to range from 166 to $195(\mu \mathrm{g} / \mathrm{L})$ with mean \pm SD $(181.8 \pm 10.9)(\mu \mathrm{g} / \mathrm{L})$ and there was a significant decrease $(\mathrm{P}<0.001)$ when compared to that of group I and group II.

$\%$ of wt of necrotic tissue to $\mathrm{LV}$ mass

In group I (I/R) \% of wt of necrotic tissue to $\mathrm{LV}$ mass was found to range from 47 to 60 with mean \pm SD $(55 \pm 4.7)$. In group II (Nesfatin-1 Pre-conditioning) $\%$ of wt of necrotic tissue to LV mass was found to range from 48 to 58 with mean \pm SD $(52.8 \pm 4.1)$. The results showed no significant change $(\mathrm{P}>0.05)$ when compared to that of group I. In group III (Nesfatin-1 Post-conditioning) \% of wt of necrotic tissue to LV mass was found to range from 21 to 34 with mean $\pm \mathrm{SD}$ (26.2 \pm 4.9$)$ and there was a significant increase $(\mathrm{P}<0.001)$ when compared to that of group I and group II.

Table 1: Effect of ischaemia reperfusion, application of Nesfatin-1 pre ischemic (100 pmol/L) and Nesfatin-1post ischemic (100 pmol/L) on all measured parameters in the three studied groups

\begin{tabular}{lcccc}
\hline parameter & $(\mathrm{n}=6)$ & $\begin{array}{c}\text { Group I } \\
(\mathbf{I} / \mathbf{R})\end{array}$ & $\begin{array}{c}\text { Group II } \\
\text { (Pre-conditioning Nesfatin-1 } \\
+ \text { I/R) }\end{array}$ & $\begin{array}{c}\text { Group III } \\
\text { (I/R + Nesfatin-1 Post- } \\
\text { conditioning }\end{array}$ \\
\hline $\begin{array}{l}\text { Left ventricular } \\
\text { pressure }(\mathrm{mmHg})\end{array}$ & $\overline{\mathrm{X}} \pm \mathrm{SD}$ & $25.6 \pm 5.8$ & $28.2 \pm 5.8$ & $69.7 \pm 5.3$ \\
\cline { 2 - 5 } & $\mathrm{p}$ & & $\mathrm{NS}^{\mathrm{a}}, \mathrm{P}<0.001^{\mathrm{c}}$ & $\mathrm{P}<0.001^{\mathrm{a}, \mathrm{b}}$ \\
\hline $\begin{array}{l}+\max (\mathrm{LV} \mathrm{dp} / \mathrm{dt}) \\
(\mathrm{mmHg} / \mathrm{s})\end{array}$ & $\overline{\mathrm{X}} \pm \mathrm{SD}$ & $1119.3 \pm 203.7$ & $1412.0 \pm 240.6$ & $2361.2 \pm 228.8$ \\
\cline { 2 - 4 } & $\mathrm{p}$ & & $\mathrm{NS} \mathrm{a}, \mathrm{P}<0.001 \mathrm{c}$ & $\mathrm{P}<0.001^{\mathrm{a}, \mathrm{b}}$
\end{tabular}

\begin{tabular}{|c|c|c|c|c|}
\hline \multirow{2}{*}{$\begin{array}{l}-\max (\mathrm{LV} \mathrm{dp} / \mathrm{dt}) \\
(\mathrm{mmHg} / \mathrm{s})\end{array}$} & $\overline{\bar{X}} \pm S D$ & $776.5 \pm 122.8$ & $982.8 \pm 117.9$ & $1263.8 \pm 111.1$ \\
\hline & $\bar{p}$ & & $N S^{a,} P<0.001^{c}$ & $\mathrm{P}<0.001^{\mathrm{a}, \mathrm{b}}$ \\
\hline \multirow{2}{*}{$\begin{array}{l}\text { Heart rate (HR) } \\
\text { (beat/min) }\end{array}$} & $\overline{\mathrm{X}} \pm \mathrm{SD}$ & $66.9 \pm 6.1$ & $79.66 \pm 5.9$ & $98.1 \pm 5.6$ \\
\hline & $p$ & & $N S^{a,} P<0.001^{c}$ & $P<0.001^{a, b}$ \\
\hline \multirow{2}{*}{$\begin{array}{l}\text { Lactate } \\
\text { dehydrogenase (LDH) } \\
\text { (IU/L) }\end{array}$} & $\overline{\mathrm{X}}_{ \pm \mathrm{SD}}$ & $199.8 \pm 21.8$ & $195.3 \pm 8.8$ & $59.5 \pm 18.7$ \\
\hline & $\bar{p}$ & & $\mathrm{NS}^{\mathrm{a}}, \mathrm{P}<0.001^{\mathrm{c}}$ & $\mathrm{P}<0.001^{\mathrm{a}, \mathrm{b}}$ \\
\hline \multirow{2}{*}{$\begin{array}{l}\text { Creatine kinase-MB } \\
\text { (CK- MB) (IU/L) }\end{array}$} & $\overline{\mathrm{X}} \pm \mathrm{SD}$ & $707.2 \pm 110.5$ & $679 \pm 114.3$ & $153.5 \pm 37.2$ \\
\hline & $p$ & & $N S^{a,} P<0.001^{c}$ & $P<0.001^{a, b}$ \\
\hline \multirow{2}{*}{$\begin{array}{l}\text { Superoxide } \\
\text { dismutase (SOD) } \\
\text { (IU/L) }\end{array}$} & $\overline{\mathrm{X}} \pm \mathrm{SD}$ & $18.7 \pm 2.5$ & $47.6 \pm 6.2$ & $113.6 \pm 3.1$ \\
\hline & $p$ & & $P<0.001^{a c}$ & $\mathrm{P}<0.001^{\mathrm{a}, \mathrm{b}}$ \\
\hline \multirow{2}{*}{$\begin{array}{l}\text { Malondialdhyde } \\
\text { (MDA) (nmol/gm } \\
\text { tissue protein) }\end{array}$} & $\overline{\mathrm{X}} \pm \mathrm{SD}$ & $6.94 \pm 1.15$ & $6.5 \pm 1.2$ & $3.04 \pm 0.83$ \\
\hline & $p$ & & $\mathrm{NS}^{\mathrm{a},} \mathrm{P}<0.001^{\mathrm{c}}$ & $\mathrm{P}<0.001^{\mathrm{a}, \mathrm{b}}$ \\
\hline \multirow{2}{*}{$\begin{array}{l}\text { C-reactive protein } \\
(\mathrm{CRP})(\mu \mathrm{g} / \mathrm{L})\end{array}$} & $\overline{\mathrm{X}} \pm \mathrm{SD}$ & $447.5 \pm 20.8$ & $336.0 \pm 25.9$ & $181.8 \pm 10.9$ \\
\hline & $\bar{p}$ & & $P<0.001^{a c}$ & $P<0.001^{a, b}$ \\
\hline \multirow{2}{*}{$\begin{array}{l}\% \text { of wt of necrotic } \\
\text { tissue to LV mass }\end{array}$} & $\overline{\mathrm{X}} \pm \mathrm{SD}$ & $55 \pm 4.7$ & $52.8 \pm 4.1$ & $26.2 \pm 4.9$ \\
\hline & $p$ & & $\mathrm{NS}^{\mathrm{a}, \mathrm{P}}<0.001^{\mathrm{c}}$ & $P<0.001^{a, b}$ \\
\hline
\end{tabular}

$\mathrm{a}=\mathrm{VS}$ group I $\quad \mathrm{b}=\mathrm{VS}$ group II $\quad \mathrm{c}=\mathrm{VS}$ group III

$\mathrm{NS}=$ non signifiant $(\mathrm{P}>0.05)$ 


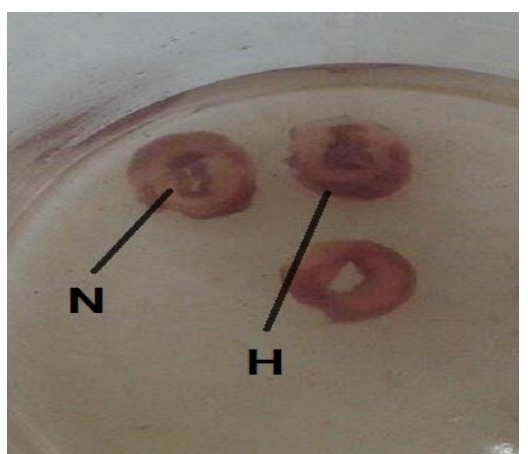

Picture (1): Left ventricle slices stained by nitro blue tetrazolium stain in group I (I/R)

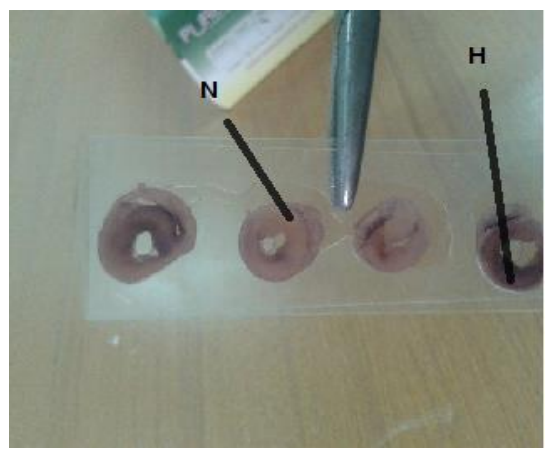

Picture (2): Left ventricle slices stained by nitro blue tetrazolium stain in group II (pre conditioning group)

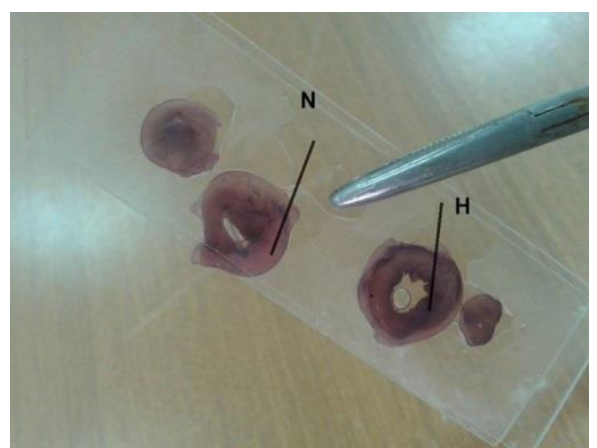

Picture (3): Left ventricle slices stained by nitro blue tetrazolium stain in group III (Post conditioning group)

*H: Stained viable tissue

*N: Unstained necrotic tissue

\section{DISCUSSION}

Cardiac ischemia followed by reperfusion still remains a serious problem in clinical procedures, such as thrombolysis, percutaneous trans-luminal coronary angioplasty and coronary bypass surgery which are the general treatment strategies of cardiovascular events ${ }^{[17]}$.

Nesfatin-1 is an 82 amino-acid hypothalamic neuropeptide reported to decrease food intake ${ }^{[1]}$, besides its expression in central nervous system; it is widely expressed peripherally and considered to be an adipocytokine ${ }^{[13,35,36]}$. Nesfatin-1 acts as an integral regulator of energy balance, circadian feeding rhythm, and related endocrine functions ${ }^{[37]}$.Its peripheral administration in normal rats decreased blood glucose level ${ }^{[38]}$. Also, in type II diabetic patients Nesfatin-1 plasma level was reported to be lower than controls ${ }^{[39]}$.

Nesfatin-1 is expressed in the ventricular cardiomyocytes $[1, \mathbf{1 3 , 4 0 ]}$ and low levels were reported in patients with AMI, which may play an important role in the development of AMI ${ }^{[16]}$.

In this study, effect of Nesfatin-1 was investigated on ischaemia reperfusion injury in isolated heart preparation of male albino rats.

The rats were divided into three groups, group (I) ischaemia-reperfusion (I/R); where the ischaemia-reperfusion protocol was applied. Group (II) (pre-conditioning group); in which Nesfatin-1 was applied20 minutes before I/R protocol. Group (III) (post-conditioning group); after I/R protocol, Nesfatin-1 was applied to hearts for 20 minutes at the beginning of the reperfusion period.

This study provides evidence that Nesfatin-1 possesses cardioprotective properties, as in group III (post conditioning group), there was a significant increase of the studied cardiac parameters. Nesfatin-1 significantly increased LVP, +max (dp/dt), -max (dp/dt) and HR compared to $\mathrm{I} / \mathrm{R}$ group. This comes in consistence with the study of Angelone et al. ${ }^{[15]}$ which stated that there is a dose dependant improvement of LVP, $+\max (\mathrm{dp} / \mathrm{dt})$ , $-\max (\mathrm{dp} / \mathrm{dt})$ and HR when Nesfatin-1 was reperfused just after ischaemic period in the first $20 \mathrm{~min}$. of reperfusion and abolished contracture development at the end of reperfusion.

In post conditioning group, Nesfatin1 caused a significant decrease in LDH and CK-MB levels, which are well known markers of myocardial damage in which the cardiac cell membrane becomes permeable or may rupture resulting in leakage of these enzymes ${ }^{[41]}$.So, Nesfatin-1 could decrease the cardiac damage and this was supported by the decrease in percentage of necrotic tissue to the LV mass in this group. These results were agreed by Angelone et al. ${ }^{[15]}$ who found a significant decrease of LDH when isolated hearts were reperfused with Nesfatin-1, as a post conditioning factor. Also, Nesfatin-1 was reported to reduce lactate dehydrogenase (LDH) release in renal $\mathrm{I} / \mathrm{R}^{[\mathbf{4 2}]}$.

Another finding in the present study is that, Nesfatin-1 caused a significant increase of SOD and a significant decrease of MDA in 
post conditioning group (group III), which are good markers of oxidative stress ${ }^{[43]}$.

A landmark study by Bolli et al. ${ }^{\text {[44] }}$ showed that potent oxidant radicals such as superoxide anion, hydroxyl radical, and peroxynitrite, are produced within the first few minutes of reflow and play a crucial role in the development of reperfusion injury. These Free radicals play a significant role in the pathogenesis of AMI ${ }^{[45]}$ and are capable of reacting with unsaturated lipids and initiating self perpetuating chain reaction of lipid peroxidation that produce MDA as a marker of oxidative damage ${ }^{[46]}$.

SOD is an oxygen radical scavenger; its localization in mitochondria as well as its inducibility in response to mid injurious stimuli suggests that SOD plays an important role in cellular defense, which can protect cells against oxidative damage by converting superoxide anion radicals that occur in the upper stream of the reactive oxygen metabolism cascade ${ }^{[47]}$ This enzyme plays important roles in oxidative stress during $\mathrm{I} / \mathrm{R}$ injury ${ }^{[48]}$.

This antioxidant role of Nesfatin- 1 in myocardial ischemia reperfusion injury is supported by other investigators who reported an anti oxidant function of Nesfatin-1 in cases of sub arachnoid heamorrhage of rat brain ${ }^{[19]}$.

Furthermore, Nesfatin-1 significantly decreased CRP level in post conditioning group (group III), indicating that Nesfatin-1 has anti inflammatory property which is protective against cardiac I/R.

This finding is in line with other investigators who concluded that, Nesfatin-1 can be protective for intestinal and renal ischemia reperfusion injury by inhibiting the generation of pro-inflammatory mediators ${ }^{[21]}$.

Also, Nesfatin-1 can alleviate gastric inflammatory damage induced by indomethacin [21]. Moreover, the administration of Nesfatin-1 after head trauma could significantly suppress gene expressions of nuclear factor kappa -B, lessen concentrations of tumor necrosis factor-alpha, interleukin-1beta and interleukin-6 which are important inflammatory mediators ${ }^{[20]}$. Furthermore, Nesfatin-1 was reported to be a new anti- inflammatory factor in case of systemic inflammation in chronic obstructive pulmonary disease (COPD) ${ }^{[49]}$ and in obstructive sleep apnea syndrome ${ }^{[50]}$.

In addition, in post conditioning group (group III); Nesfatin-1 significantly decreased the percentage of necrotic tissue to the whole LV mass. This is in agree with Angelone et al ${ }^{[15]}$ who reported a similar effect when Nesfatin1 was administered in vitro during the first 20 minutes of reperfusion in case of myocardial I/R.

Thus, it can be concluded that, Nesfatin-1 postconditioning in group III produced a cardioprotective effect via anti-oxidant and anti-inflammatory effects.

The cardioprotective role of Nesfatin- 1in post conditioning group can be explained by many mechanisms reported by other researchers; first, Nesfatin- 1 activates the novel $\mathrm{PKC}$ isoform as $\mathrm{PKC} \theta, \mathrm{PKC} \varepsilon$ and $\mathrm{PKCe}$ in ventricular myocytes ${ }^{[39]}$.PKC $\theta$ and $\mathrm{PKC} \varepsilon$ are considered the most important isoenzymes protecting the heart from reperfusion injury and preserve systolic function, at least in part, by preventing cardiomyocyte cell death. In addition, PKCe may act on mitochondria to affect cellular survival reducing both necrosis and apoptosis [51,52]

Nesfatin-1 diminished activity of the apoptotic enzyme caspase-3 as well as reduced number of apoptotic neuronal cells in traumatic rat brain tissues ${ }^{[20]}$ and tubular apoptotic cells in renal $\mathrm{I} / \mathrm{R}^{[42]}$. This indicates that Nesfatin-1 has anti-apoptotic effects.

Second, in rat ventricular myocytes, the nitric oxide synthase(NOS) produces nitric oxide (NO) which by targeting soluble guanylatecyclase (GC) increases protein kinase $\mathrm{G}(\mathrm{PKG})$, which in turn negatively affects contractility by reducing the phosphorylating troponin I ${ }^{[53]}$. It was reported that Nesfatin-1 can inhibit NO production via impairment of cGMP production ${ }^{[54,55]}$,furthermore, chronic peripheral nesfatin1 administration can decrease endothelial nitric oxide synthase (eNOS) level at the acute phase of ischemia/reperfusion, this will serve two functions simultaneously; limitation of reperfusion flow and counteraction of cardiac depression produced by $\mathrm{NO}^{[56]}$. On the contrary, Angelone et al ${ }^{[15]}$ concluded that 
NO was not involved in the cardioprotective effect of nesfatin-1 in their study.

Biomolecular studies showed that signal transducer and activator of transcription-3 (STAT3) and Extracellular signal-regulated kinases1/2 (ERK1/2) take part to the Nesfatin-1-mediated post-conditioning ${ }^{[15]}$. It is known that STAT is an important membrane to-nucleus signaling for many stress responses, which include I/R, oxidative stress, and hypoxia ${ }^{[44,57]}$.It is also a crucial member of protective cascades that, when activated, induces survival signals in the infracted myocardium ${ }^{[\mathbf{5 8 , 5 9 ]}}$.

Notably, in group (II) (pre conditioning group), Nesfatin-1 produced no significant effect on cardiac function parameters; LVP, $+\max (\mathrm{dp} / \mathrm{dt}),-\max (\mathrm{dp} / \mathrm{dt})$ and HR and the infracted area size, despite, the significant increase in level of SOD and the significant decrease in CRP level in this group, indicating that Nesfatin-1 has a minor role in preconditioned ischaemic heart.

It is important to distinguish between the effects of ischemia and the effects of reperfusion on the heart. Necrosis does not occur during ischemia, but rather during the subsequent reperfusion, and this has been attributed to production of excessive reactive oxygen radicals ${ }^{[60]}$, which are an important mechanism of reperfusion injury, when molecular oxygen is reintroduced into a previously ischemic myocardium, undergoes a sequential reduction leading to the formation of oxygen free radicals and the influx of the inflammatory cells, leading to rupture of the cell membrane ${ }^{[61]}$. Those deleterious effects were counteracted by giving Nesfatin-1 during reperfusion as a post-conditioning factor (group III), but this was not the case if given before ischemia (group II).

The resulting decrease in CRP in case of Nesfatin-1 preconditioning (group II) could be attributed to its intrinsic biological properties as an acute-phase reactant in case of ischaemic heart disease. In contrast, none of the other systemic markers of inflammation, whether upstream cytokine mediators other sensitive acute-phase proteins has such characteristics ${ }^{\left[{ }^{[62}\right]}$.This also explained the sensitivity of this marker to anti-inflammatory effect of Nesfatin-1 as a preconditioning factor. The case may be the same for the increased levels of SOD induced by Nesfatin-1 preconditioning, being the most sensitive anti-oxidant ${ }^{[63]}$.

However, this antioxidant and antiinflammatory role of Nesfatin-1in preconditioning group was not sufficient to protect the heart and improve its functions. This may be due to the timing of administration being given before ischemia not during the reperfusion period in the course of myocardial $\mathrm{I} / \mathrm{R}$.

\section{Acknowledgment}

The authors appreciate the efforts of Prof/ Kamal Eleshishi, Pathology departmentFaculty of Medicine, Zagazig University for performing the histopathological study and Prof / Somiaa Hassan, Biochemistry department-Faculty of Medicine, Zagazig University for performing the biochemical assay tests.

\section{R/EFERENCES:}

1. Oh-I S, Shimizu H, Satoh T, Okada S, Adachi $\mathrm{S}$, Inoue K, Eguchi H, Yamamoto M, Imaki T, Hashimoto $\mathrm{K}$, Tsuchiya $\mathrm{T}$, Monden $\mathrm{T}$, Horiguchi K, Yamada M, Mori M. Identification of nesfatin-1 as a satiety molecule in the hypothalamus. Nature. 2006; 443: 709-712.

2. Garcia-Galiano D, Navarro VM, Gaytan F, Tena-Sempere M. Expanding roles of NUCB2/nesfatin-1in neuroendocrine regulation. J Mol Endocrinol. 2010a; 45: 281290.

3. Yamawaki H. Vascular effects of novel adipocytokines: focus on vascular con-tractility and inflammatory responses. Biol Pharm Bul. 2011; 34:307-310.

4. Elmquist JK, Coppari R, Balthasar N, Ichinose M, Lowell BB. Identifying hypothalamic pathways controlling food intake, body weight, and glucose homeostasis. J Comp Neurol. 2005, 493(1):63-71

5. Stengel A, Taché Y (2013):Role of brain NUCB2/nesfatin-1 in the regulation of food intake. Curr Pharm; 19(39): 6955-6959.

6. Kohno D, Nakata M, Maejima Y, Shimizu H, Sedbazar U,Yoshida N, Dezaki K, Onaka T, Mori M, Yada T. Nesfatin-1 neurons in paraventricular and supraoptic nuclei of the rat hypothalamus coexpress oxytocin and vasopressin and are activated by refeeding. Endocrinol. 2008; 149: 1295-1301 
7. Aydin S. Role of NUCB2/nesfatin-1 as a possible biomarker. Curr Pharm Des. 2013; 19(39): 6986-6992.

8. Mortazavi S, Gonzalez R, Ceddia R, Unniappan S. Long-term infusion of nesfatin-1 causes a sustained regulation of whole-body energy homeostasis of male Fischer 344 rats. Front Cell Dev Biol. 2015; 3: 22.

9. Ramanjaneya M, Chen J. Identification of nesfatin-1 in human and murine adipose tissue: a novel depot-specific adipokine with increased levels in obesity. Endocrinol. 2010; 151: 3169-3180.

10.Li QC, Wang HY, Chen X, Guan HZ, Jiang ZY. Fasting plasma levels of nesfatin-lin patients with type 1 and type 2 diabetes mellitus and the nutrient-related fluctuation of nesfatin-1 level in normal humans. Reg Pept. 2010; 159: 72-77.

11.Su Y, Zhang J, Tang Y, Bu F, Liu JN. The novel function of nesfatin-1: Antihyperglycemia. Biochem Biophys Res Commun. 2010; 391(1): 1039-1042.

12.Ozkan Y, Suay S, Aydin S, Aksoy A, Sahin I, Timurkan M, Citil C, Kalayci M, Catak Z. Orexigenic and anorexigenic peptides in obesity. Reg. Pep. 2013; Article in press

13. Stengel A, Goebel M, Wang L, Rivier J, Kobelt P, Mo"nnikes H, Lambrecht NW, Tache' Y. Central nesfatin-1 reduces darkphase food intake and gastric emptying in rats: differential role of corticotropin-releasing factor2 receptor. Endocrinol. 2009; 150: 49114919.

14. Mohan H, Unniappan S. Ontogenic pattern of nucleobindin-2/nesfatin-1 expression in the gastroenteropancreatic tissues and serum of Sprague Dawley rats. Reg Pep. 2012; 175: 6169.

15. Angelone T, Filice E, Pasqua T, Amodio N, Galluccio M, Montesanti G, Quintieri AM, Cerra MC. Nesfatin-1 as a novel cardiac peptide: identification, functional characterization, and protection against ischemia/reperfusion injury. Cell Mol Lif Sci. 2013; 70 (3): 495-509.

16.Dai H, Li X, He T, Wang Y, Wang Z, Wang S, Xing M, Sun W, Ding H (2013): Decreased plasma nesfatin-1 levels in patients with acute myocardial infarction. Pept; 46: 167-171

17. Hausenloy DJ, Yellon DM. Myocardial ischemia-reperfusion injury:a neglected therapeutic target. J Clin Invest. 2013; 123(1).

18.Parlakpinar H, Orum MH, Sagir M. Pathophysiology of Myocardial Ischemia
Reperfusion Injury. Med Sci. 2013; 2(4): 935954.

19. Ozsavci D, Ozakpinar OB, Cevik O, Demirel GY, Sener A, Oba R, Sener G. The Effects of Peptide Hormone Ghrelin on Platelet Apoptosis. Thromb Res. 2014; 133: 101.

20.Tang $\mathrm{CH}, \mathrm{Fu} \mathrm{XJ}, \mathrm{Xu} \mathrm{XL}$, Wei XJ, Pan HS. The anti-inflammatory and anti-apoptotic effects of nesfatin-1 in the traumatic rat brain. Pept. 2012; 36: 39-45.

21.Kolgazi M, Cantali-Ozturk C, Deniz R, Ozdemir-Kumral ZN, Yuksel M, Sirvanci S, Yeğen BC. Nesfatin-1 alleviates gastric damage via direct antioxidant mechanisms. J Surg Res. 2015; 193: 111-118.

22.Cappello S, Angelone T, Tota B, Pagliaro P, Penna C, Rastaldo Corti A R, Losano G, Cerra MC. Human recombinant chromogranin Aderived vasostatin-1 mimics preconditioning via an adenosine/nitric oxide signaling mechanism. Am J Physiol Heart Circ Physiol. 2007; 293: 719-727.

23. Rastaldo R, Cappello S, Folino A, Di Stilo A, Chegaev K, Tritto I, Pagliaro P, Losano G. Low concentrations of an nitric oxide-donor combined with a liposoluble antioxidant compound enhance protection against reperfusion injury in isolated rat hearts. $\mathrm{J}$ Physiol Pharmacol. 2010b; 61: 21-27.

24.Pagliaro P, Mancardi D, Rastaldo R, Penna C, Gattullo D, Miranda KM, Feelisch M, Wink DA, Kass DA, Paolocci N. Nitroxyl affords thiol-sensitive myocardial protective effects akin to early preconditioning. Free Radic Biol Med. 2003; 34(1): 33-43Induced by High Fat Diet in Rats. PLoS ONE; 11(2): e0148402

25.Han J, Wang D, Yu B, Wang Y, Ren H, Zhang B, Wang Y, Zheng Q. Cardioprotection against Ischemia/Reperfusion by Licochalcone $\mathrm{B}$ in isolated rat hearts. Oxidat Med Cell Long. 2014; e134862

26.Deng C, Sun Z, Tong G, Yi W, Ma L, Zhao B,Cheng L,Zhang J,Cao F,YiD. $\alpha$-Lipoic acid reduces infarct size and preserves cardiac function in rat myocardial ischemia/ reperfusion injury through activation of PI3K/Akt/Nrf2 pathway. PLOS ONE. 2013; 8: e 58371.

27. Marques-Neto SR, Castiglione RC, Pontes A, Oliveira DF, Ferraz EB, Nascimento JM, Bouskela E (2016): Effects of Incretin-Based Therapies on Neuro-Cardiovascular Dynamic Changes

28.Penna C, Mancardi D, Rastaldo R, Losano G, Pagliaro P. Intermittent activation of bradykinin $\mathrm{B} 2$ receptors and mitochondrial 
KATP channels trigger cardiac postconditioning through redox signaling. Cardiovasc Res. 2007; 75(1):168-177.

29. Moss DW, Henderson AR, Kachmar JF. Fundamentals of clinical chemistry. Philadelphia. 1987; 3: 346-421

30.Rosaki SB.Creatine phosphokinase-A spectrophotometric method with improved sensitivity. Am J Clin Pathol. 1967; 50: 89-97.

31.Szasz G, Gruber W, Bernt E. Creatine kinase in serum: 1. Determination of optimum reaction conditions. Clin. Chem. 1976; 22: 650-656.

32.Kakkar P, Das B, Viswanathan PN. A modified spectrophotometric assay of superoxide dismutase. Indian $\mathbf{J}$ Biochem Biophys. 1984; 21: 130-132.

33.Ridker PM, Buring JE, Shih J, Matias M, Hennekens $\mathrm{CH}$. Prospective Study of CReactive Protein and the Risk of Future Cardiovascular Events Among Apparently Healthy Women. Circ. 1998; 98: 731-733.

34. Ohkawa H, Ohishi W, Yagi K. Assay for lipid peroxides in animal tissues by thiobarbituric acid reaction. Anal Biochem. 1979; 95 : 351358.

35. Stengel A, Tache Y. Nesfatin-1 role as possible new potent regulator of food intake. Regul Pept. 2010; 163: 18-23.

36. Goebel-Stengel $M$, Wang $L$. Central and peripheral expression and distribution of NUCB2/nesfatin-1. Curr Pharm Des. 2013; 19: 6935-6940.

37.Garcia-Galiano D, Navarro VM, Roa J, RuizPino F, Sanchez-Garrido MA, Pineda R, Castellano JM, Romero M, Aguilar E, Gayta'n F, Die' guez C, Pinilla L, Tena-Sempere M. The anorexigenic neuropeptide, nesfatin-1, is indispensable for normal puberty onset in the female rat. J Neurosci. 2010b; 30: 7783-7792.

38. Riva M, Nitert MD, Voss U, Sathanoori R, Lindqvist A, Ling C, Wierup N. Nesfatin-1 stimulates glucagon and insulin secretion and beta cell NUCB2 is reduced in human type 2 diabetic subjects. Cell Tiss Res. 2011; 346(3): 393-405.

39. Yin Y, Li Z, Gao L, Li Y, Zhao J, Zhang W. AMPK-dependent modulation of hepatic lipid metabolism by nesfatin-1.Mol Cell Endocrinol. 2015; 417: 20-26.

40.Price TO, Samson WK, Niehoff ML, Banks WA. Permeability of the blood-brain barrier to a novel satiety molecule nesfatin-1. Pept. 2007; 28: 2372-2381.
41. Oliver IT. A spectrophotometric method for the determination of creative phosphokinase and myokinase. Biochem J. 1955; 61: 116-120

42.Jiang $G$, Wang $M$, Wang $L$, Chen $H$, Chen $Z$, Guo J, Weng X, Liu X. The protective effect of nesfatin-1 against renal ischemia-reperfusion injury in rats. Ren Fail. 2015; 37(5): 882-889.

43. Mathew S, Menon PV, Kurup PA, Metais C, Bianchi C, Li J, Simons M, Sellke FW. Effect of administration of vitamin A, ascorbic acid and nicotinamide adenine dinucleotide and flavine adenine nucleotide on severity of myocardial infarction induced by isoproterenol in rats. Indian J Exp Biol. 2001; 23: 500-504.

44.Bolli R, Jeroudi MO, Patel BS, et al. Direct evidence that oxygen-derived free radicals contribute to post ischemic myocardial dysfunction in the intact dog. Proc Natl Acad Sci U S A. 1989; 86: 4695-4699.

45.Loeper J, Goy J, Rozenstajin L, Bedu O, Moisson. Lipid peroxidation and protective enzymes during myocardial infarction. Clin Chim Acta. 1991; 196: 119-125

46. Shrinivas K, Bhaskar MV, Aruna Kumari R, Nagraj K, Reddy KK. Antioxidants, lipid peroxidation and lipoproteinsin primary hypertension. Ind Heart J. 2000; 52(3):285288.

47. Muthel CM, Glenz Y, Klaus M, Radermacher $\mathrm{P}$, Speit G, Leverve X. Influence of an orally effective SOD on hyperbaric oxygen-related cell damage. Fre Radic Res. 2004; 38 (9): 927-932.

48. Mittler R. Oxidative stress, antioxidants and stress tolerance. Tren Plan Sci. 2002; 7 (9): 405-410.

49.Leivo-Korpela S, Lehtimäki L, Hämälainen M, Vuolteenaho K, Kööbi L, Järvenpää R, Moilanen E. Adipokines NUCB2/nesfatin-1 and visfatin as novel inflammatory factors in chronic obstructive pulmonary disease. Med inflamm. 2014; 2014:e232167

50. Shen P, Han Y, Cai B, Wang Y. Decreased levels of serum nesfatin-1 in patients with obstructive sleep apnea syndrome. Sleep Breath. 2015; 19(2): 515-522.

51.Pagliaro P, Moro F, Tullio F, Perrelli MG, Penna C. Cardioprotective pathways during reperfusion: focus on redox signaling and other modalities of cell signaling. Antioxid Redox Signal. 2011; 14(5): 833-850.

52. Hausenloy DJ, Lecour S, Yellon DM. Reperfusion injury salvage kinase and survivor activating factor enhancement prosurvival signaling pathways in ischemic 
postconditioning: two sides of the same coin. Antioxid Redox Signal. 2011; 14(5): 893-907.

53.Abi-Gerges N, Fischmeister R, Me'ry PF. G protein-mediated inhibitory effect of a nitric

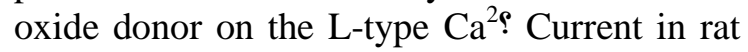
ventricular myocytes. J Physiol. 2001; 531: $117-130$.

54. Springer J, Azer J, Hua R, Robbins C, Adamczyk A, McBoyle S, Bissell MB, Rose RA. The natriuretic peptides BNP and CNP increase heart rate and electrical conduction by stimulating ionic currents in the sinoatrial node and atrial myocardium following activation of guanylyl cyclase-linked natriuretic peptide receptors. J Mol Cell Cardiol. 2012; 52(5): 1122-1134

55. Yamawaki $H$, Takahashi $M$, Mukohda $M$, Morita T, Okada M, Hara Y. A novel adipocytokine, nesfatin-1 modulates peripheral arterial contractility and blood pressure in rats. Biochem Biophys Res Commun. 2012; 418: 676-681.

56. Ayada C, Toru U, Korkut Y. Nesfatin-1 and its effects on different systems. Hippokratia. 2015a; 19 (1): 4-10

57. Mascareno E, El-Shafei M, Maulik N, Sato M, Guo Y, Das DK،Siddiqui MA. JAK/STAT signaling is associated with cardiac dysfunction during ischemia and reperfusion. Circ. 2001; 104: 325-329.

58.Xuan YT, Guo Y, Han H, Zhu Y, Bolli R. An essential role of the JAK-STAT pathway in ischemic preconditioning. Proc Natl Acad Sci USA. 2001; 98: 9050-9055.

59. Boengler K, Hilfiker-Kleiner D, Heusch G, Schulz R. Inhibition of permeability transition pore opening by mitochondrial STAT3 and its role in myocardial ischemia/reperfusion.Basic Res Cardiol.2010; 105: 771-785.

60. Borutaite V, Morkuniene R, Arandarcikaite O, Jekabsone A, Barauskaite J, Brown GC. Nitric oxide protects the heart from ischemia-induced apoptosis and mitochondrial damage via protein kinase $G$ mediated blockage of permeability transition and cytochrome $\mathrm{c}$ release. J Biomed Sci.2009; 16: 70.

61.Garcia-Dorado D. Myocardial reperfusion injury: a new view. Cardiovasc Res.2004; 61: 363-364.

62.Pepys MB, Hirschfield GM C-reactive protein: a critical update. J Clin Invest. 2003; 111: 1805-1812.

63.Lindau-Shepard B, Shaffer JB, Vecchio PJD. Overexpression of manganous superoxide dismutase (MnSOD) in pulmonary endothelial cells confers resistance to hyperoxia. J Cell Physiol. 1994; 161: 237-22 